\title{
Design Sprint: 5 Hari Desain Produk untuk Sukses Wirausaha
}

\author{
Agung Purnomo \\ Institut Teknologi Kreatif Bina Nusantara Malang \\ agung.purnomo@binus.ac.id
}

\section{Pengantar}

Design Sprint merupakan suatu kerangka desain produk fleksibel yang berguna untuk memaksimalkan peluang membuat sesuatu yang diinginkan orang. Ini adalah upaya sangat cocok dilakukan oleh tim kecil di mana hasilnya akan menentukan arah untuk produk atau layanan. Design Sprint diciptakan oleh Jake Knapp dan dikembangkan di Google Venture pada tahun 2010 [3]. Design Sprint membantu seluruh anggota tim guna meraih arah dan tujuan dengan jelas. Saat tim yang anda susun sedang membutuhkan suntikan motivasi maka Design Sprint bisa menjadi solusinya. Atau bagi anda yang diawal memulai bisnis juga sangatlah cocok menggunakan konsep ini untuk mengetahui keinginan konsumen dan hal apa yang ingin anda tawarkan melalui produk yang anda gagas [1].

\section{Penggunaan Design Sprint}

Kapankah saat yang paling tepat untuk penggunaan Design Sprint?. Design Sprint ini dapat diimplementasi pada momentum [1]:

1. Awal Proyek

Anda dapat menggunakan Design Sprint pada saat anda memulai inovasi konsep produk yang akan anda gunakan. Ini bekerja dengan baik ketika anda menjelajahi peluang dengan tujuan menghasilkan konsep-konsep asli yang akan diuji di dunia nyata.

2. Ditengah Proyek

Design Sprint digunakan untuk memperluas konsep yang sudah anda miliki atau dengan kata lain sebagai mengeksplorasi cara-cara baru untuk menggunakan produk-produk yang sudah ada.

3. Proyek yang Matang

Design Sprint dapat dijadikan sebagai menguji suatu produk. Ini akan membuat anda lebih fokus terhadap suatu aspek yang harus anda diperbaiki dalam suatu produk. 


\section{Fase Desain Sprint}

Implementasi suatu Design Sprint pada umumnya terdiri dari lima fase diskrit [2], yakni:

1. Hari pertama: Understand

Hari pertama design sprint ini digunakan untuk menyamakan gelombang/persepsi terhadap pembahasan produk. Hasil terpenting dari hari pertama ini adalah sketch user story.

2. Hari kedua: Diverge

Menggali dan menemukan beberapa tawaran solusi dengan ragam kegiatan yang menarik, seperti silent critique, crazy eights, mind map, dan lain-lain.

3. Hari ketiga: Decide

Pada langkah dihari ketiga ini beberapa solusi yang diperoleh dari langkah hari kedua, diberikan suatu porsi yang pas, relevan dan diulas dengan metode praktis tertentu untuk dapat dikreasi suatu prototype.

4. Hari keempat: Prototype

Satu hari untuk prototype, hal yang dilakukan dengan kerja sama tim dan beberapa tips serta trik yang bisa digunakan untuk menuntaskan prototype.

5. Hari kelima: Validate

Pada langkah hari terakhir ini prototype diujicoba secara langsung praktek lapang kepada calon pengguna. Segala hal yang berlangsung direkam dan dicatat di suatu ruang observasi. Hasil nyata dari tindakan validate ini akan sangat menentukan pada proses selanjutnya, yaitu apakah termasuk iterasi besar atau iterasi kecil.

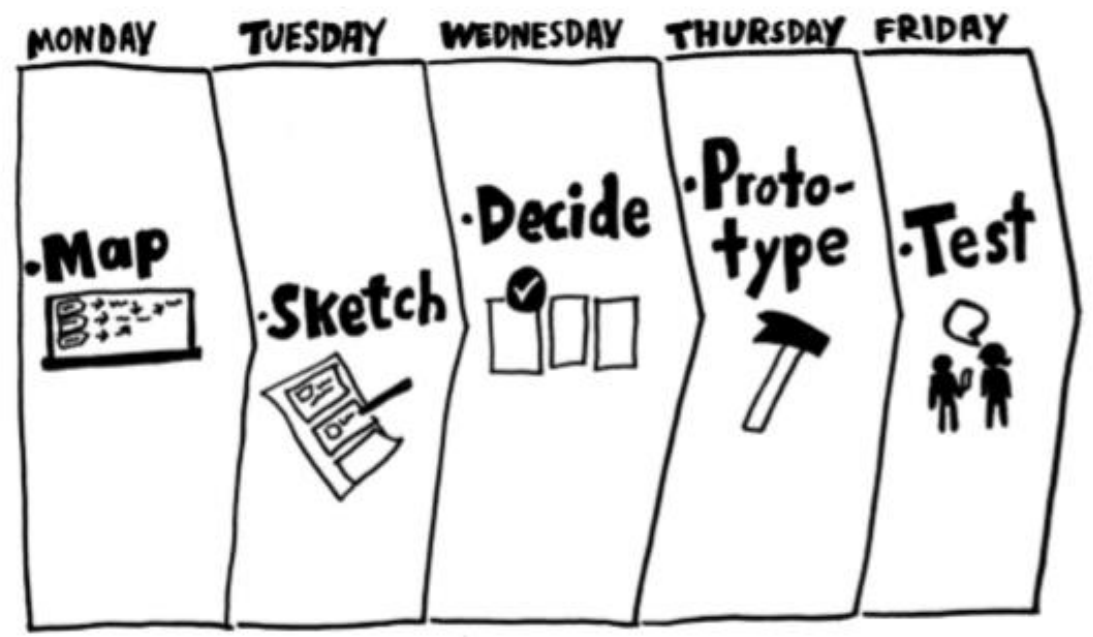

Gambar 1. Google Ventures Design Sprint 5-day process 


\section{Prinsip Design Sprint}

Ada semangat yang dibangun di tiap-tiap proses didalamnya seperti layaknya metodologi yang lainnya. Ada beberapa prinsip dan karakter yang harus dijaga konsistensinya. Prinsip-prinsip tersebut juga dimaksudkan untuk membangun pengembangan diri tim menjadi lebih baik. Berikut adalah prinsip dari Design Sprint [2], yaitu:

1. Openmind

Openmind merupakan hal dianggap terpenting dalam metode design sprint ini. Setiap organisasi yang ingin berinovasi, siap untuk berinovasi, harus memiliki sifat dan karakter openmind. Openmind tidak hanya cuma mendengarkan pengguna, namun juga mampu beradaptasi tatkala terdapat informasi ataupun ide baru konstruktif yang datang.

2. Minimize Group Brainstorming

Semangat dari design sprint merupakan minimize group brainstorming dengan cara diberikan takaran yang cukup besar untuk individual tanpa harus dikritik terlebih dahulu atau diganggu dan sesudahnya berikan suatu kesempatan dari masing-masing tim anggota untuk menyampaikan pendapat, ide, solusi secara totalitas, dengarkan dengan seksama semua pemaparan dan tetap berkepala dingin sampai benar-benar mengerti paparan tersebut. Langkah ini akan menjadi diskusi yang produktif guna saling mengerti dan melengkapi bukan untuk menjatuhkan sehingga ide sekaligus solusinya akan kian kuat membumi.

3. Menghargai waktu dan proses

Berdasarkan pengalaman yang ada, ketika kondisi terdesak banyak hal yang perlu dikorbankan guna mencapai tujuan. Fokus terhadap tujuan tanpa mengabaikan proses/tahapan/disiplin yang baik, maka hasilnya pun akan baik pula. Lawan dari fokus adalah distraction/gangguan/pengalihan. Untuk itu selalu waspada terhadap distraction karena godaan untuk mengaburkan value yang mau dicapai akan selalu ada. Komitmen untuk menuntaskan suatu pekerjaan dengan batasan waktu dan proses yang ketat, akan mengurangi distraction yang akan muncul.

4. Design Thinking Thinker

Design thinking menggabungkan empati, kreatifitas, dan rasionalitas untuk memecahkan human-centered problem. Empati digunakan untuk melihat sesuatu dari perspektif pengguna dan memposisikan dirinya dalam menghadapi masalahnya. Banyak sisi yang bisa dilihat yaitu dari teknologi, 
finansial, politik, agama, manusia dan budaya. Sehingga dari perspektif tersebut akan digali dan ditemukan pemahaman yang holistik. Kreatifitas merupakan kesempatan untuk suatu penemuan hal yang baru dan segar. Kreativitas umumnya akan menghasilkan konsep dan solusi. Melalui empati, tim akan memiliki banyak sudut pandang yang akan membuka ragam kesempatan yang dikenal sebagai kreativitas. Rationalitas berusaha menyesuaikan ragam solusi untuk dapat diujicoba serta diukur secara kualitatif dan kuantitatif.

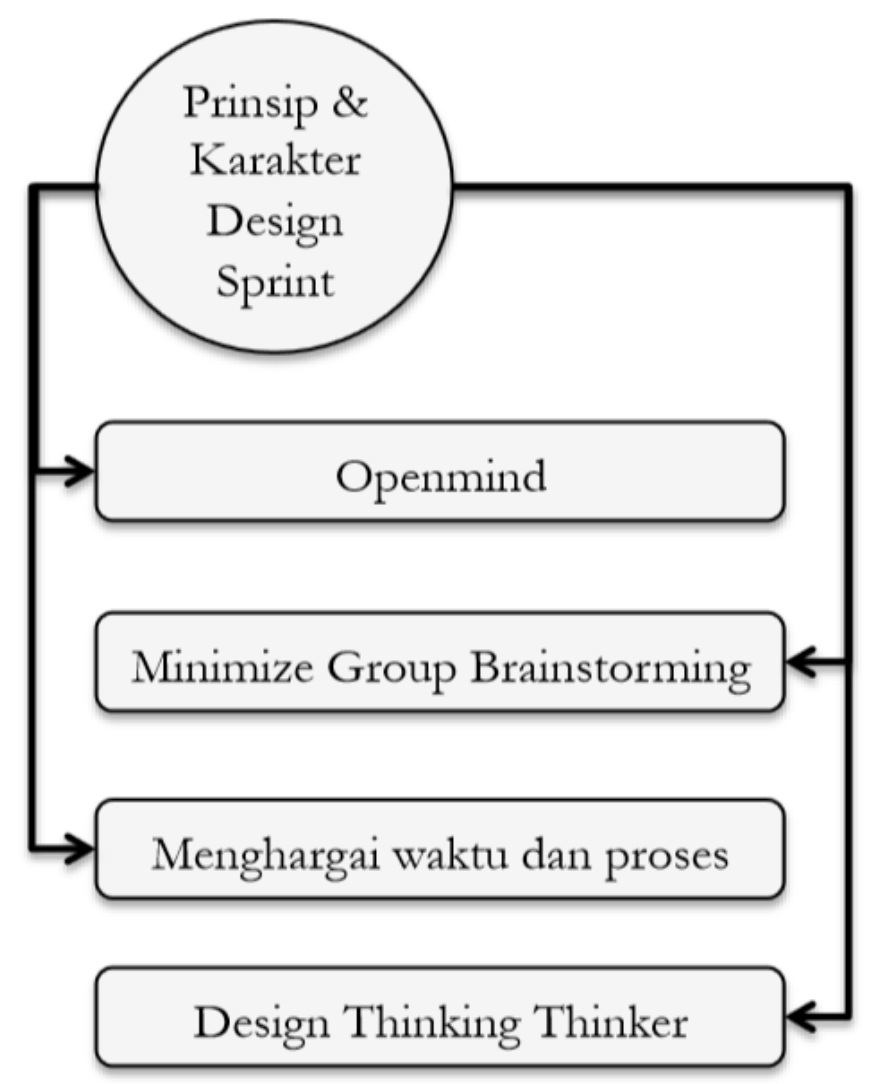

Gambar 2. Prinsip dan Karakter Design Sprint

\section{Kesimpulan}

Design Sprint merupakan kerangka desain produk fleksibel yang berguna untuk memaksimalkan peluang membuat sesuatu yang diinginkan orang yang dikembangkan oleh Google Venture. Design Sprint ini dapat diaplikasikan pada saat awal proyek, ditengah proyek dan proyek yang matang. Implementasi Design Sprint terdiri dari lima fase yaitu: understand, diverge, decide, prototype dan validate. 
Prinsip design sprint diantaranya: openmind, minimize group brainstorming, menghargai waktu dan proses, dan design thinking thinker.

\section{References}

1. Banfield, R., Lombardo, C. T., \& Wax, T. (2015). Design Sprint: A Practical Guidebook for Building Great Digital Productsdesign. United States of America: O'Reilly Media, Inc.

2. Knapp, J., (2016). Sprint: How to Solve Big Problems and Test New Ideas in Just Five Days. New York: Simon \& Schuster.

3. Yasha. (2017, November 9). Memahami Google Design Sprint Demi Kesuksesan Bisnis. Retrieved January 1, 2019. From https://www.dewaweb.com/blog/google-design-sprint/ 